\title{
A COMMUNITY BASED STUDY ON THE PREVALENCE OF BEHAVIORAL RISK FACTORS OF NON-COMMUNICABLE DISEASES IN DAVANGERE CITY, KARNATAKA
}

Raghavendra Swamy Koppad ${ }^{1}$, Girish H. $\mathrm{O}^{2}$

\section{HOW TO CITE THIS ARTICLE:}

Raghavendra Swamy Koppad, Girish. H. O. "A Community-Based Study on the Prevalence of Behavioral Risk Factors of Non-Communicable Diseases in Davangere City, Karnataka". Journal of Evolution of Medical and Dental Sciences 2014; Vol. 3, Issue 08, February 24; Page: 1841-1849 DOI: 10.14260/jemds/2014/2067

ABSTRACT: BACKGROUND: As we slowly advance into the $21^{\text {st }}$ Century, we find that the challenges posed by non-communicable diseases (NCDs) present an imminent threat to people worldwide. The rapidly growing epidemic of non-communicable diseases is clearly related to changes in life styles. OBJECTIVES: 1) To study the socio-demographic factors of the region. 2) To assess the prevalence of behavioral risk factors for non-communicable diseases. METHODS: Study Design: A Communitybased cross-sectional descriptive study. Study Participants: 2000 urban people of Davangere city, belonging to the age group 15-64 years. Study Period: $1^{\text {st }}$ December 2008 and 30 ${ }^{\text {th }}$ November 2009 (1 year). METHODOLOGY: A multi-stage sampling method with households as sampling unit. Information on behavioral risk factors was obtained through standardized methods as recommended by the STEPS 1 survey guideline of the World Health Organization after modifying to suit the local requirement. Statistical Analysis: Proportion and Chi-square test. RESULTS: Total participants in the study were 2000, comprised of 1000 males' and1000 females. High burden of NCD risk factors was observed among urban population: current smoking- 15.2\% (Male-30.1\%, Female-0.2\%); current smokeless tobacco use $-17.8 \%$ (Male-28.8\%, Female-6.8\%); current alcohol use $-17.5 \%$ (Male-32.8\%, Female-1.3\%); physical inactivity-30.4\% (Male-17.6\%, Female-43.3). INTERPRETATION AND CONCLUSIONS: Substantially high levels of the various behavioral risk factors in this urban population suggest an urgent need for adopting healthy life style modifications among the population in general. The increased risk observed among the younger generation for risk factors such as smoking, alcohol consumption calls for urgent corrective steps and measures for longterm monitoring of all major risk factors as well as the major chronic disease conditions.

KEYWORDS: Non-Communicable Diseases, Smoking, Alcohol, WHO STEPS, Behavioral Risk Factors.

INTRODUCTION: As we slowly advance into the 21 $1^{\text {st }}$ Century, we find that the challenges posed by non-communicable diseases (NCDs) present an imminent threat to people worldwide. Globalization delivers the uniform cause for the spread of chronic diseases to every corner of the World . ${ }^{1}$ Chronic non-communicable diseases (CNCDs) are reaching epidemic proportions worldwide. These diseases which include cardiovascular conditions (mainly heart disease and stroke), some cancers, and chronic respiratory conditions and type 2 diabetes mellitus - affect people of all ages, nationalities and classes. ${ }^{1}$

Chronic non-communicable diseases (CNCDs) are the leading cause of death in the World. ${ }^{1}$ Accounting for around $60 \%$ of all deaths and $44 \%$ of premature deaths worldwide. ${ }^{2}$ The rapidly growing epidemic of non-communicable diseases is clearly related to changes in life styles. ${ }^{3}$

India too illustrates the phenomenon of "health transition" which positions NCDs as a major public health challenge of growing magnitude in the $21^{\text {st }}$ century. The incidence of Cardio vascular 
diseases (CVDs) and other NCDs are greater in urban areas when compare to rural areas in India. ${ }^{4}$ NCDs account for 53 and 44\% of all deaths and disability-adjusted life years (DALYs) respectively in India. ${ }^{5}$ According to World Health Report 2002, cardiovascular diseases (CVDs) will be the largest cause of death and disability by 2020 in India. ${ }^{6}$ Currently Indians experience CVDs deaths at least a decade earlier than their counterparts in countries with established market economies (EME). ${ }^{7}$

Since the underlying risk factors for all the NCDs are common, therefore primordial prevention of occurrence of risk factors along with their early identification and management can help delay the progress to non-communicable diseases. ${ }^{4}$ With this scenario of the health situation, it is important to study the burden of non-communicable diseases risk factors using Indian data to know the real dimensions of the problem and work towards preventive measures. ${ }^{3}$ Hence a community based study on prevalence of behavioral risk factors for non-communicable diseases in Davangere city among 15-64 years of population was undertaken, with the intention that the results of this study will provide necessary inputs for effective non communicable disease control in this region.

\section{OBJECTIVES:}

$>$ To study the socio-demographic factors of the region.

$>$ To assess the prevalence of behavioral risk factors for non-communicable diseases.

\section{METHODOLOGY:}

Study Design: A Community-based cross-sectional descriptive study.

Study Period: $1^{\text {st }}$ December 2008 and 30th November 2009 (1 year).

Study Area: Davangere City.

Study Population: Data was collected from house hold members aged 15-64 years, who were residents of Davangere city.

Sample Size: Based on previous nationwide household survey, lowest prevalence of noncommunicable diseases, about $5 \%$ was considered for the study.

Using Formula,

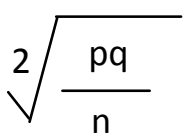

Substituting values we got sample size of 1900. (Approximately 2000).

ETHICAL CLEARANCE: Taken from ethical committee of J.J.M. Medical College, Davangere.

COLLECTION OF DATA: Multistage sampling was used. The study included males and females in the age group of 15-64 years and this age group was further stratified in to five age and sex categories, each stratum with 10 years interval. There were 400 individuals in each of these strata, with this the total effective sample size of the study became 2000. In Davangere urban there are 40 wards, $20 \%$ of wards were selected for the study by simple random sampling method and which came to about 8 wards. In each of these wards, houses were selected by systematic random sampling procedure by visiting every " $\mathrm{k}$ " the house (data on number of houses in each ward was obtained from records of 
Municipal Corporation of Davangere City). From each house one person was interviewed according to need.

All subjects in the sample were informed about the purpose of the study. After obtaining the informed consent they were interviewed using a pre-structured and pretested questionnaire adopted from WHO STEPS 1 approaches for non-communicable diseases risk factors surveillance, after modifying to suit the local requirements. ${ }^{8}$ Data was collected for following,

STEP 1: Information on socio-demographic variables and behavioral NCD risk factors including smoking tobacco, smokeless tobacco, alcohol consumption, physical activity (Job, Leisure time and Travel related physical activities). All the standard parameters and definitions were used according to WHO-STEPS recommendations. ${ }^{8}$

DATA ANALYSIS STATISTICAL TESTS: Data was analyzed by using Percentage proportions, Pearson's Chi-square $\left(\mathrm{X}^{2}\right)$ tests.

\section{RESULTS:}

Of the total 2000 participants, 1000 were males \& 1000 were females. All participants were in the age group of 15- 64 years. The age group was divided in to five categories of 10 years age interval, in each category there were 400 participants with equal number of males and females (Male-200, Female-200). (Table: 1).

Majority $(78.5 \%)$ of the subjects were belonging to Hindu religion, followed by Muslims (20.6\%) and Christians (0.9\%). Majority of the participants were literate (83.7\%), while few were illiterate (16.3\%). (Table: 2 ).

Most of the participants were home makers (32.5\%), followed by unskilled workers (21.5\%) and semiskilled (1.8\%) workers. (Table: 3 ).

The prevalence of current smoking was 15.3\%; among them almost all subjects were daily smokers (prevalence-15.2\%). The prevalence of daily smoking habit was $30.1 \%$ among males, but the same was $0.2 \%$ among females. The mean age of initiation of smoking among men was 23.4 years. Among daily smokers the mean duration of smoking was $23.1+14.9$ years. (Table: 4 ).

Prevalence of smoking was found to be highest in the age group of 55-64 years (33.7\%), followed by $26.7 \%$ in $45-54$ years and $22.4 \%$ in 35 -44years. Prevalence of smoking was least in the age group of 25-34 years (7.9\%). Increase in the prevalence of smoking as age increased among participants was found highly significant $(\mathrm{P}<0.001)$. (Table 5) Regarding type of smoking, the data revealed that the habit of using cigarette $(70.2 \%)$ was more than beedi $(27 \%)$ and pipe $(2.6 \%)$. Average frequency of smoking among daily smoking men was 13.8/ day. (Not shown in table).

The study revealed that $17.7 \%$ of the subjects were current oral tobacco users, while few were used it in the past (0.4\%). Prevalence of daily smokeless tobacco use was $17.8 \%$, it was noticed that the prevalence was found more in males $(28.8 \%)$ than females $(6.8 \%)$. (Table: 6$)$.

(Table 7). The most common form of smokeless form of tobacco used was chewing tobacco (66.2\%), followed by gutka (33.8\%). The mean age of initiation of the same was $24.2 \pm 7.9$ years. Among daily users the mean duration of using smokeless tobacco was $24.8+14.9$ years among participants. Average frequency of using oral tobacco was 7 per day. 
Overall, the prevalence of consumption of smokeless tobacco increased with the age. Prevalence of smokeless tobacco use was more in the age group of 45-54years (23.6\%), while it was found to be least in the age group of 15-24 years (17.7\%). (Fig. 1).

Alcohol consumption was defined as ever used alcohol in the lifetime, it was $23.1 \%$. Consumption was more prevalent among men (44.6\%), compared to women (1.6\%). This difference was found statistically significant $(\mathrm{P}<0.001)$.Among total alcohol users, current alcohol use (within 12 months) was observed in $73.8 \%$ of participants. (Table: 8 ).

Prevalence of current alcohol use was $17.5 \%$ and prevalence was more among men (32.8\%) than women $(1.3 \%)$. This difference was found statistically highly significant $(\mathrm{P}<0.001)$. (Table: 9$)$.

Leisure time sedentary activities were more prevalent among all the age groups, which is followed by job related and travel related sedentary activities in that order. Job related (69.3\%) and travel (44.3\%) related sedentary activities were more prevalent among the age group of 55-64 years as compared to other age groups, while leisure time physical activities were more prevalent in the age group of 35-44years (88.7\%). Overall prevalence physical inactivity (includes work, leisure time and while going and coming from market) was found 30.4\%. (Fig. 2).

DISCUSSION: The risk factors of today are the diseases of tomorrow. Identifying these risk factors in populations occupies a central place in the surveillance system. Prevalence of smoking in our study was $15.2 \%$. This finding is supported by the multi centric study conducted in Chandigarh, Delhi, Kanpur, and Bangalore (15.6\%). ${ }^{9}$ Prevalence of smokeless tobacco was $17.9 \%$ in our study. Study conducted by Joshi et al ${ }^{10}$ reported more prevalence (32.7\%) compared to our study. Present study revealed that prevalence of chewing form of tobacco was more seen in older age group of 45-64 years and this finding is supported by the studies conducted by Joshi et al and Sen $U$ et al.10,11

Usage of smoking tobacco (Male $-30.4 \%$ and Women $-0.2 \%$ ) and smokeless tobacco (Male $29 \%$ and Women $-6.8 \%$ ) were high in males, in the present study. This can be attributed to the fact that in the Indian population mostly men indulge in this unhealthy practice. This is also reported in other studies by Joshi et al, Meenakshi BM et al, Gupta OP et al, Thankappan KR, Suguthan T N et al and Nath et al.10,12-16

The prevalence of current alcohol use in the present study was $17.5 \%$. Prevalence was more among males (32.8\%) compared to females (1.3\%). A multi centric study conducted by Bela shah et al reported that prevalence of alcohol use was 40 - 50\% in men, is slightly more than our study finding. ${ }^{17}$ As noted above, women had a very low prevalence of alcohol intake, suggesting potentially beneficial influences of social mores.

In the present study, $66 \%$ of the subjects performed sedentary activities during working hours; similarly, 38.9\% used motorized vehicle for travel and $84.5 \%$ were sedentary at leisure time. This could be attributable to poor awareness and high use of paid labor by housewives and use of mechanized means in kitchen preparations by females, leading to sedentary life style. Similarly, in men also, higher use of motorized vehicles and mechanization at workplaces lead to inactivity. The prevalence of overall physical inactivity among the free living urban population, in the present study was found to be $30.4 \%$. The result of the present study is comparable with figures (31-51\%) given by the WHO, and findings are also in accordance with studies conducted by Suguthan TN et al in Kerala and Nath et al.14,15,18 Studies conducted by Meenakshi BM et al, Gupta R et al reported much high prevalence $(>70 \%)$ of overall sedentary activities in urban population as compared to our study. ${ }^{19}$ 


\section{RECOMMENDATIONS:}

- Strengthening the evidence for NCD prevention and control by assessing its burden and risk factors through NCD risk factors surveillance.

- A nationwide initiative to create awareness among the people regarding the harmful effects of tobacco and alcohol, with main focus on children, adolescents and adults, so as to deter early initiation of smoking and alcohol.

- Effective implementation of COTPA (Cigarette Other Tobacco Product Act), to prevent the advertisement of tobacco products and to prevent use of cigarette in public places, as well as legislation to reduce alcohol intake.

\section{REFERENCES:}

1. Daar A S, Singer P A et al. Grand challenges in chronic non-communicable diseases. NATURE 22 November 2007; 450: 494-496.

2. World Health Organization. Preventing Chronic Diseases. A vital investment [Online]. 2005 [cited 2008 Aug 21]; Available from: URL:http://www.paho.org/english/ad/dpc/nc/cmn-poconcept.pdf

3. Assessment of Burden of Non-communicable Diseases [Online]. [Cited 2008 Aug 21]; Available from:

URL:http://www.whoindia.org/LinkFiles/Assessment_of_Burden_of_NCD_Introduction_Assess ment_of_Burden_of_NCDs.pdf.

4. Srinath Reddy K. Prevention and Control of Non-Communicable Diseases: Status and Strategies. Working paper no.104. Indian Council For Research On International Economic Relations [Online]. July 2003 [cited 2008 Aug 21]. Available from: URL:http:www.icrier.org/pdf/WP104.pdf

5. Mehan MB, Srivatsav N, Panday H. Profile of Non-communicable Disease Risk Factors in an Industrial setting. J Postgrad Med September 2006; 52 (3): 167-171.

6. Ischaemic Heart Diseases- Acute Myocardial Infarction Standard Treatment Guidelines [Online]. [cited 2008 Aug 24]; Available from:

URL:http://www.mohfw.nic.in/nrhm/stg/PDF\%20Content/STG\%20Select\%20Conditions/Acu te\%20Myocardial\%20Infarction.pdf

7. National Cardiovascular Disease Database. Supported by Ministry of Health \& Family Welfare. Government of India and World Health Organization [Online]. [cited 2008 Oct 6]; Available from: URL:http://www.whoindia.org/LinkFiles/NMH_Resources_National_CVD_databaseFinal_Report.pdf

8. WHO STEPS Instrument: Core and Expanded. The WHO Stepwise approach to Surveillance of chronic non-communicable diseases risk factors [Online]. [cited 2008 July 6]; Available from: URL:http://asaha.com/ebook/UNzE1MTg-/Part-5--STEPS-Instrument-Overview.pdf

9. Thakur JS. Chandīgarh: The first smoke-free city in India. Indian Journal of Community Medicine July 2007; 32 (3): 169-170.

10. Joshi U, Modi B, Yadav S. A Study on Prevalence of Chewing form of Tobacco and Existing Quitting Patterns in Urban Population in Urban Population of Jam Nagar, Gujarat. Indian Journal of Community Medicine January 2010; 35 (1): 105-108. 
11. Sen U, Basu A. Factors Influencing Smoking Behavior among Adolescents. Asian Pac J Cancer Prev 2000; 1: 305-9.

12. Meenakshi Bakshi Mehan, Somila Surabhi, Gautami J. Solanki. Risk factors profile of Noncommunicable diseases among middle -income (18-65 years) free living urban population of India. Int J Diab Der Crres 2006 Dec; 26:169-76.

13. Thankappan K R, Bela Shah et al. Risk factor profile for chronic non-communicable diseases: Results of a community-based study in Kerala, India. Indian J Med Res 2010 January; 131: pp 53-63.

14. Sugathan TN, Soman CR, Sunkaranarayana K. Behavioural risk factors for non-communicable diseases among adults in Kerala, India. Indian J Med Res 2008 Jun; 127:555-563.

15. Anitha N, Sunil G, Sila D, Anannya R, Ravneeth K. A Study of the Profile of Behavioral Risk Factors of Non- Communicable Diseases in an Urban setting Using the WHO STEP1 Approach. Ann Trop Med Public Health Jan - June 2009; 2 (1): 15-19.

16. Gupta OP, Phatak S. Pandemic Trends in Prevalence of Diabetes Mellitus and Associated Coronary heart diseases in India- Their cause and prevention. Int J of Diab Dev Ctries 2003; 23: 37-50.

17. Bela Shah, Prashant Amthur. Risk factor Surveillance for Noncommunicable diseases (NCDs): The Multi-site ICMR-WHO Collaborative Initiative. Presentation made at Forum 9; 2005 12-16 September; Mumbai, India.

18. Webb GP. Nutrition: A health promotion approach. 2nd ed. London: 2002. p. 86.

19. Gupta R, Sarna M, Thanvi J, Rastogi P, Kaul V, Gupta VP. High prevalence of coronary risk factors in Panjabi Bhatia community: Jaipur Heart Watch - 3. Indian Heart J 2004; 56: 646-652.

\begin{tabular}{|c|c|c|c|c|}
\hline Age groups (Yrs.) & Males & Females & Total & Percentage \\
\hline $15-24$ & 200 & 200 & 400 & 20 \\
\hline $25-34$ & 200 & 200 & 400 & 20 \\
\hline $35-44$ & 200 & 200 & 400 & 20 \\
\hline $45-54$ & 200 & 200 & 400 & 20 \\
\hline $55-64$ & 200 & 200 & 400 & 20 \\
\hline Total & $\mathbf{1 0 0 0}$ & $\mathbf{1 0 0 0}$ & $\mathbf{2 0 0 0}$ & $\mathbf{1 0 0}$ \\
\hline Table 1: Age \& sex wise distribution of participants
\end{tabular}

\begin{tabular}{|l|c|c|}
\hline \multicolumn{1}{|c|}{ Variable } & Variable categories & Number (\%)N=2000 \\
\hline \multirow{2}{*}{ Religion } & Hindu & $1570(78.5)$ \\
\cline { 2 - 3 } & Muslim & $412(20.6)$ \\
\cline { 2 - 3 } & Christian & $18(0.9)$ \\
\hline \multirow{2}{*}{ Education level } & Illiterate & $326(16.3)$ \\
\cline { 2 - 3 } & Literate & $1674(83.7)$ \\
\hline
\end{tabular}

Table 2: Religion \& education of participants 
ORIGINAL ARTICLE

\begin{tabular}{|c|c|c|}
\hline Occupation & Number & Percentage \\
\hline Professional & 38 & 1.9 \\
\hline Semi professional & 80 & 4 \\
\hline Clerical/ Shop/ Farm & 281 & 14.1 \\
\hline Skilled Worker & 195 & 9.8 \\
\hline Semi-skilled worker & 37 & 1.8 \\
\hline Unskilled Worker & 430 & 21.5 \\
\hline Home maker & 650 & 32.5 \\
\hline Students & 289 & 14.4 \\
\hline Total & 2000 & 100 \\
\hline
\end{tabular}

\begin{tabular}{|l|c|c|c|}
\hline $\begin{array}{c}\text { Smoking } \\
\text { Status }\end{array}$ & $\begin{array}{c}\text { Men } \\
\text { Number (\%) }\end{array}$ & $\begin{array}{c}\text { Women } \\
\text { Number (\%) }\end{array}$ & $\begin{array}{c}\text { Total } \\
\text { Number (\%) }\end{array}$ \\
\hline Daily & $301(30.1)$ & $2(0.2)$ & $303(15.2)$ \\
\hline Occasionally & $4(0.4)$ & 0 & $4(0.2)$ \\
\hline Never & $683(68.3)$ & $998(99.8)$ & $1681(84.1)$ \\
\hline Past Smokers & $12(1.2)$ & 0 & $12(0.6)$ \\
\hline \multicolumn{1}{|c|}{ Total } & $1000(100)$ & $1000(100)$ & $2000(100)$ \\
\hline
\end{tabular}

Table 4: Current Smoking Status in men and women

\begin{tabular}{|c|c|c|}
\hline \multirow{2}{*}{ Age group } & \multicolumn{2}{|c|}{ Smoking Tobacco } \\
\hline & Yes Number (\%) & No Number (\%) \\
\hline $15-24$ & $28(9.2)$ & $372(21.9)$ \\
\hline $25-34$ & $24(7.9)$ & $376(22.1)$ \\
\hline $35-44$ & $68(22.4)$ & $332(19.5)$ \\
\hline $45-54$ & $81(26.7)$ & 319 (18.7) \\
\hline $55-64$ & $102(33.7)$ & $298(17.5)$ \\
\hline Total & $303(100)$ & $1697(100)$ \\
\hline
\end{tabular}

Table 5: Relation between age and smoking tobacco

\begin{tabular}{|l|c|c|c|}
\hline $\begin{array}{c}\text { Smoking } \\
\text { Status }\end{array}$ & $\begin{array}{c}\text { Men } \\
\text { Number (\%) }\end{array}$ & $\begin{array}{c}\text { Women } \\
\text { Number (\%) }\end{array}$ & $\begin{array}{c}\text { Total } \\
\text { Number (\%) }\end{array}$ \\
\hline Daily & $288(28.8)$ & $68(6.8)$ & $356(17.8)$ \\
\hline Occasionally & $2(0.2)$ & 0 & $2(0.1)$ \\
\hline Never & $704(70.4)$ & $930(93)$ & $1634(81.7)$ \\
\hline Past users & $6(0.6)$ & $2(0.2)$ & $8(0.4)$ \\
\hline \multicolumn{1}{|c|}{ Total } & $1000(100)$ & $1000(100)$ & $2000(100)$ \\
\hline
\end{tabular}

Table 6: Current Smokeless Tobacco use in Men and Women 


\begin{tabular}{|c|c|c|c|}
\hline Types & $\begin{array}{c}\text { Men } \\
\text { Number (\%) }\end{array}$ & $\begin{array}{c}\text { Women } \\
\text { Number (\%) }\end{array}$ & $\begin{array}{c}\text { Total } \\
\text { Number (\%) }\end{array}$ \\
\hline Gutka & $119(41.7)$ & 0 & $119(33.8)$ \\
\hline Chew Tobacco & 169 (58.3) & $68(100)$ & $237(66.2)$ \\
\hline Total & $288(100)$ & $68(100)$ & $356(100)$ \\
\hline
\end{tabular}

\begin{tabular}{|c|l|l|l|}
\hline Consumption & \multicolumn{1}{|c|}{$\begin{array}{c}\text { Men } \\
\text { Number (\%) }\end{array}$} & $\begin{array}{c}\text { Women } \\
\text { Number (\%) }\end{array}$ & $\begin{array}{c}\text { Total } \\
\text { Number (\%) }\end{array}$ \\
\hline Ever & $446(44.6)$ & $16(1.6)$ & $462(23.1)$ \\
\hline Never & $554(55.4)$ & $984(98.4)$ & $1538(76.9)$ \\
\hline Total & $1000(100)$ & $1000(100)$ & $2000(100)$ \\
\hline \multicolumn{4}{|c|}{$\mathbf{X}^{2}=\mathbf{5 2 0 . 4 ,}$ P< 0.001 HS } \\
\hline
\end{tabular}

Table 8: Alcohol Consumption in Men and Women

\begin{tabular}{|c|c|c|c|}
\hline Consumers & $\begin{array}{c}\text { Men } \\
\text { Number (\%) }\end{array}$ & $\begin{array}{c}\text { Women } \\
\text { Number (\%) }\end{array}$ & $\begin{array}{c}\text { Total } \\
\text { Number (\%) }\end{array}$ \\
\hline Yes & $328(32.8 \%)$ & $13(1.3 \%)$ & $341(17.5 \%)$ \\
\hline No & $672(67.2 \%)$ & $987(98.7 \%)$ & $1659(83 \%)$ \\
\hline Total & $1000(100 \%)$ & $1000(100 \%)$ & $2000(100 \%)$ \\
\hline \multicolumn{4}{|c|}{$\mathrm{X}^{2}=350, \mathrm{P}<0.001$ Highly Significant } \\
\hline
\end{tabular}

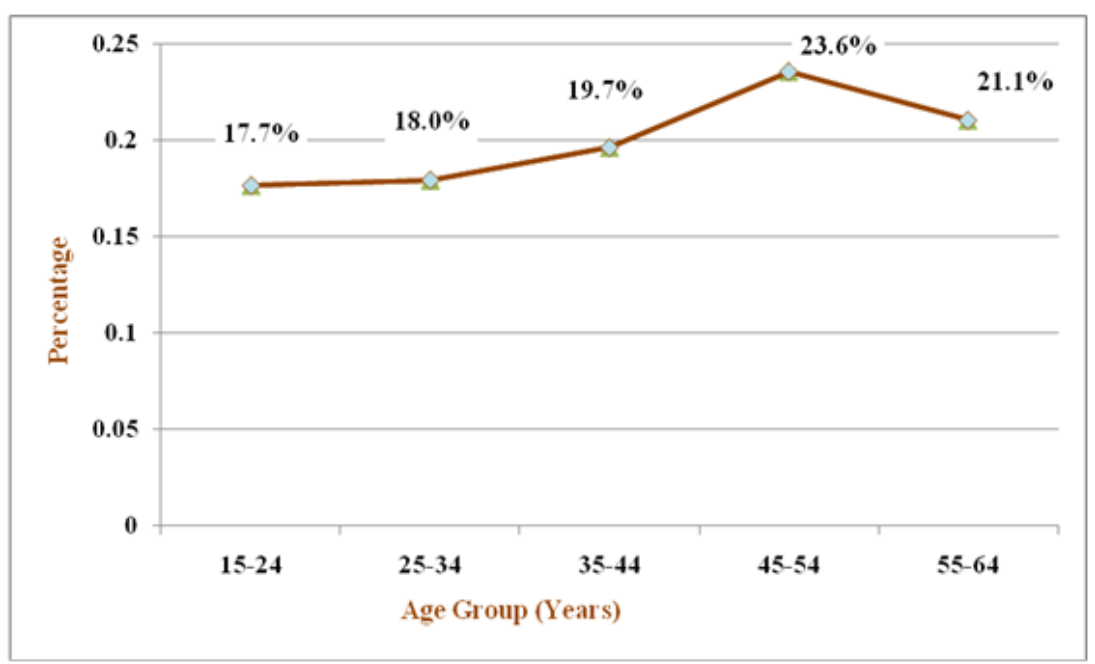

Figure 1: Age- wise distribution of smokeless tobacco 
ORIGINAL ARTICLE

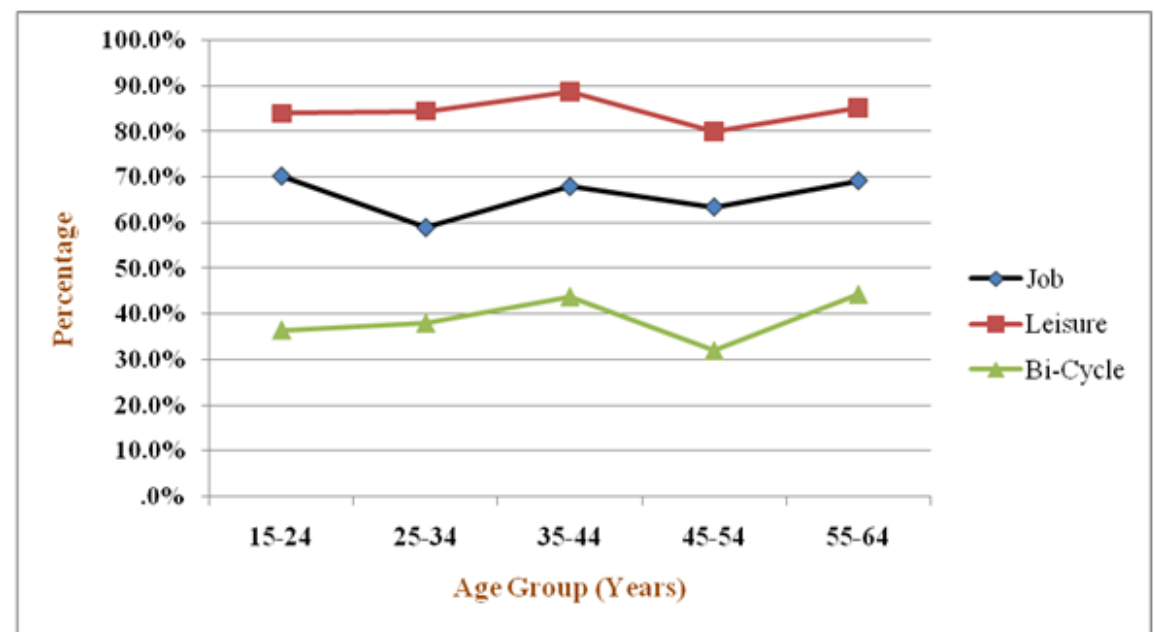

Figure 2: Age-wise distribution of physical in-activities

\section{AUTHORS:}

1. Raghavendra Swamy Koppad

2. Girish H. O.

\section{PARTICULARS OF CONTRIBUTORS:}

1. Assistant Professor, Department of Community Medicine, Shimoga Institute of Medical Sciences.

2. Assisatant Professor, Department of Community Medicine, Subbaiah Institute of Medical Sciences.

\section{NAME ADDRESS EMAIL ID OF THE} CORRESPONDING AUTHOR:

Dr. Girish H.O,

Assistant Professor,

Department of Community Medicine,

Subbaiah Institute of Medical Sciences,

Shimoga, Karnataka.

E-mail: dr.girishmysore@gmail.com

Date of Submission: 06/02/2014.

Date of Peer Review: 07/02/2014.

Date of Acceptance: 14/02/2014.

Date of Publishing: 18/02/2014. 